\title{
1 Communities, ecosystem engineers, and functional domains
}

2 Jean-François Ponge

3 Muséum National d'Histoire Naturelle, CNRS UMR 7179, 91800 Brunoy, France

$4 \quad$ E-mail: ponge@mnhn.fr

$5 \quad$ Phone number: +33678930133

6 Short running title: Communities, ecosystem engineers, and functional domains

7 Key words: communities, boundaries, ecosystem engineers, interactions, global change

8 Type of article: Current topics in ecology

9 Number of words in the abstract: 162

10 Number of words in the main text: 5708

11 Number of references: 168 


\section{Abstract}

14 Communities are shaped by the activity of ecosystem engineers, which modify their environment to

15 their benefit and that of subordinate species within their functional domain. Communities are defined as embedded assemblages of interactions, from cells to landscapes. They are threatened by present-day

17 global changes which trigger the invasive nature of ecological engineers, with cascading effects. This perspective paper starts with a definition of ecosystem engineers and functional domains in the frame of developments in community ecology. Then I show that the concepts of ecosystem engineer and functional domain explain (i) most of the observed cases of community boundaries, and (ii) the passage from small-scale interactions among individuals to community-wide processes of dynamics and stability. I will further show that ecological engineering exists at various scales, from viruses to landscapes, functional domains being embedded in a flexible manner. At last, I will show that threats posed by global changes to communities are mainly mediated by their negative or positive effects on ecosystem engineers.

\section{Keywords}




\section{INTRODUCTION}

Do communities really exist and if yes, how are they shaped by organisms and their environment? Are they just a mind view, or the result of true biological processes? Community ecology long-time questioned the existence of biotic interactions within communities. Non-existence views are represented by the arbitrary combination of populations as in the individualistic concept of Gleason (1939) and the recent neutral theory of Hubbell (2001). The second view of the existence of interactions has a much longer history, from the balance of nature of Linné (1762) and Darwin (1859) to modern ecologists. Interactions of populations have been supposed in the succession theory of Clements (1916) and in the consumer-resource model of MacArthur (1970). The organization of communities has been mostly studied through the description of food web structures (Pimm, 1980), and by modelling interactions among species involved in competition for resources (Tilman, 1982) and prey-predator relationships (Abrams, 1986). However, fruitful ideas about the role of biogenic habitats (habitats that are created and modified by organisms) to explain communities did not emerge before the turn of the century, with new habitat concepts coined by e.g. Huston (1994), Jones et al. (1994), Takeda (1995). Before that, habitats had been defined as physical arrangements of objects in space (Bell et al., 1990). Jones et al. (1994) coined the term of 'ecosystem engineers', designing “... organisms that directly or indirectly modulate the availability of resources to other species, by causing physical state changes in biotic or abiotic materials. In so doing [ecosystem engineers] modify, maintain and create habitats", thereby offering a biological background to the concept of habitat. Then this term became popular in terrestrial as well as aquatic ecology (Roman et al., 2014), while many ecologists still focused their researches on species interactions without taking biogenic habitats in account (Ratzke et al., 2020). Taking the soil as the background Lavelle and co-workers (Lavelle, 2002; Lavelle et al., 2005, 2016) associated to every soil engineer a functional domain, which they defined as a specific environment produced by a population or community of allogenic soil engineers.

In a second section dealing with community boundaries I will suggest extending the above definition of the functional domain to every kind of ecosystem engineer. I also suggest extending it to 
autogenic engineers (e.g. trees, coral reefs), by considering that the boundary of their functional domain is their own boundary, even after death (e.g. standing dead trees, bleached coral reefs). One may wonder how species or species individuals might positively interact within the community or negatively interact among communities, if they are not in physical or chemical contact (Callaway, 2002) or if they do not share the same resources (Heard, 1994; Tilman, 2004). One may also wonder whether species interactions $(i)$ vary according to the random occurrence of selfish species arriving in the same environment, the so-called 'mass effect' (Leibold et al., 2004), or (ii) result from the mutual adaptation of coevolving species, the so-called 'ghost of competition past' (Connell, 1980). This is the subject of the third section showing that the concepts of ecosystem engineers (Jones et al., 1994, 1997) and functional domains (Lavelle, 2002; Lavelle et al., 2005, 2016) explain how communities are shaped and organized. At first, it should be clearly expressed that our definition of the community embraces all organisms which are living together in a given ecosystem, including plant, animals and microbes, and not a single group of organisms living together, e.g. a community of birds or insects, which has only a heuristic value and does not mean anything from a functional point of view (Putman, 1994).

In the fourth section, communities as well as ecosystems (the community plus the physical environment) will be envisaged at various scales, e.g. a rhizosphere can be considered as an ecosystem as well as a forest or a lake, according to the updating by Ponge (2015) of the original definition of the ecosystem given by Tansley (1935).

At last, I will show in a fifth section that the fate of communities, as faced to present-day global changes, relies for a large part on the fate of ecosystem engineers, as this can be deduced from the decisive influence of ecosystem engineers and their functional domains on the composition and boundary of communities, and that at all scales.

\section{COMMUNITIES ARE SHAPED BY ECOSYSTEM ENGINEERS}

I suggest that the concept of ecosystem engineer may explain most of the observed cases of community boundaries. In their seminal paper Jones et al. (1994) define ecosystem engineers as "organisms that directly or indirectly modulate the availability of resources (other than themselves) to 
other species, by causing physical state changes in biotic or abiotic materials." They distinguish autogenic engineers, which "change the environment via their living and dead tissues," e.g. trees, corals, and allogenic engineers which "change the environment by transforming living or non-living materials from one physical state to another, via mechanical or other means," e.g. earthworms, termites. A consequence of paramount importance of this distinction is that once an autogenic ecosystem engineer disappears (e.g. deforestation, coral bleaching), the whole system it created collapses. In the case of an allogenic ecosystem engineer, survival of the system it created is expected to occur after its death, at least for a limited amount of time.

Functional domains are "parts of the environment influenced by a major biotic or abiotic regulator' (Lavelle, 2002). As examples given in the soil by this author, the drilosphere and the rhizosphere, i.e. the volume of soil under the proximate influence of an earthworm or of a root, are functional domains of earthworms and roots, respectively. Although the concept of functional domain has been originally coined for soil engineers, I suggest to extend it to the huge variety of ecosystem engineers so far identified (Wright \& Jones, 2006). In the case of autogenic engineers the functional domain is delineated by the engineering organism itself while in the case of allogenic engineers its boundary corresponds to the part of the environment which is modified by the activity of the engineering organism. Another consequence of the distinction between allo- and autogenic engineers is that the former allows positive interactions with another organism having engineering properties, as in the intermingling functional domains of roots and earthworms, with a function synergy between them (Jacquiod et al., 2020), a typical case of 'cooperative ecosystem engineering' (Passarelli et al., 2014). In the case of autogenic engineers a synergy may exist between their functional domains provided they are self-compatible. For instance, functional domains of trees growing in tight association coalesce and interact positively to endow the forest ecosystem with original properties, e.g. microclimate, which can be disrupted by badly adapted forestry practices (Aussenac, 2000). Ecosystem engineers create heterogeneity by locally modifying ecological factors within their functional domain (Jouquet et al., 2007). A discontinuity appears between 'inside' and 'outside' parts of the newly delimited functional domain, whether ecosystem engineers are autogenic or allogenic, 
starting the establishment of a community. This boundary favours interactions between different parts of the created ecosystem and disfavours interactions with the surrounding ecosystems, according to the definition of the ecosystem given by Tansley (1935) as "the whole system. (in the sense of physics), including not only the organism-complex, but also the whole complex of physical factors forming what we call the environment of the biome - the habitat factors in the widest sense". Functional domains fluctuate in space and time according to life duration and dispersal rate of the ecosystem engineer to which they are associated (Commito et al., 2005). They may also disappear locally through nutrient depletion (Wright et al., 2004) or be destroyed on a large scale, e.g. by human overexploitation (Coleman \& Williams, 2002). However, functional domains remain generally stable, being limited only by the tolerance of ecosystem engineers to environmental constraints (e.g. upper tree lines along latitudinal or altitudinal gradients) or to other coexisting (but antagonistic) ecosystem engineers (Castorani et al., 2014).

The passage from small-scale processes (e.g. the action of individuals on their immediate environment) to community-level patterns (e.g. vegetation types) is an emergent property which can be explained by amplification and connectedness (Ponge 2005a). Examples and consequences for the fair management of vegetation can be found in Alex Watt's famous articles "Pattern and process in the plant community" (Watt, 1947) and "The community and the individual" (Watt, 1964), both based on his long-term observations on the dynamics of woodland, heathland and grassland vegetation. Alex Watt was successful in his attempt to reconcile community-unit (Clements, 1916, 1936) and individualistic (Gleason, 1926, 1939) views, by showing that communities can only be understood by taking in account biotic and abiotic processes which contribute to their early appearance and further dynamics, either in a perpetual state of change around an equilibrium point or along successional trends, according to autogenic or allogenic processes. He was also the first to stress the importance of organisms he called "dominant" and which are now rated as "ecosystem engineers". Watt's views are also present in the concept of "forest architecture" developed by Roelof Oldeman to explain cyclic and successional processes taking place at various scales in the dynamics of natural forest stands (Oldeman, 1990). The notion of "zero-event", i.e. the event which creates a gap in the canopy cover 
(e.g. by storms, fire, or the natural death of dominant trees), helps to understand why small units of particular vegetation, including trees but also many other associated organisms, including understory vegetation, herbivores, parasites and decomposers, persist in the course of time with clear delineation from the surroundings.

In a seminal paper Yamamura (1976) demonstrated mathematically that abrupt changes might occur at population level along smooth environmental gradients, thus without the presence of any ecological barriers. This demonstration, which holds also for time transitions (e. g. successions), was later confirmed by Wilson et al. (1996). Danz et al. (2013) showed that discontinuities in species composition occurred along a continuous environmental gradient, and they were able to discard dispersal limitation as well as ecological barriers as explanatory processes. They studied by numerical methods changes in floristic composition before European settlement, thus in the absence of humanmediated disturbances, along transects crossing boundaries between forest and prairie biomes in Minnesota. Their study took place along an aridity gradient comparable to the well-known Wisconsin prairie gradient, at the birth of the continuum concept (Curtis, 1955). In both studies climate was passing from the arid conditions prevailing east of the Rocky Mountains to the more rainy conditions prevailing near the Great Lakes. In both studies differences in the reaction norms of various plant species in a gradient of water availability could be at first sight thought to explain the observed variation in floristic composition (Rajakaruna et al., 2003). However, Danz et al. (2013) used a spatially-explicit model to analyse their data, while Curtis (1955) projected his species on an axis describing water availability, i.e. without resorting to vicinity. Curtis original data were later reanalysed by Umbanhowar (1992) using multivariate methods but, here too, without any inclusion of the geographic positions of sample plots and this author confirmed the existence of a moisture-driven continuum. We may ask whether the observed discrepancy between Wisconsin and Minnesota studies was due to the methods used or to differences in the vegetation itself. It should be noted that Danz et al. (2013) studied forest-prairie boundaries while Curtis (1955) studied a gradient within the single prairie biome. This is an indirect clue that trees could be responsible for something else than just a change in floristic composition driven by species water requirements. Interestingly Milne et al. (1996) 
showed that the abrupt boundary between shrub and grassland canopies in southwestern USA can be explained by the theory of spatial phase transitions (Domb \& Lebowitz, 2000). Briefly, each tree canopy modifies the environment (e.g. light, nutrients, space) for other species of lesser stature, cohabitation of both occurring only before a threshold of tolerance is attained, depending on the degree of coalescence of tree canopies. The boundary between the two phases (e.g. forest and prairie) is thus a reflectance at community-level of individual tolerance thresholds. The boundary between forest and savanna has been explained by the same principles (Abades et al., 2014) and the rate of the present-day worldwide encroachment of woody vegetation over grassland or savanna (Archer et al., 2017) has been calculated accordingly (Loehle et al., 1996).

Other typical cases of line demarcations within vegetation landscapes exist, too. Among many others, let us cite wind-induced wave regeneration lines along slopes in Japanese (Iwaki \& Totsuka, 1959) and US (Sprugel, 1976) coniferous forests, or banded or patchy vegetation patterns in semi-arid environments (Ludwig et al., 1999; Sileshi et al., 2010). In all cases so far reported in the absence of any ecological barriers a keystone species (Paine, 1969) or a keystone functional group (Ortiz et al., 2013 ) is in play, interacting with the biotic or abiotic environment and modifying it to the advantage of some species and to the disadvantage of some others. Such organisms, whether plants (e.g. trees), animals (e.g. termites, ants, earthworms), or microbes (e.g. fungal mycelia), have been called ecosystem engineers (Jones et al., 1994; Jouquet et al., 2006; Cameron, 2010).

The notion of community boundary cannot be separated from that of ecosystem boundary if we consider that environmental changes resulting from the activity of ecosystem engineers take a prominent part in delineating a community. As an example a study of intermingling forest and heathland ecosystems in the French northern Alps showed that the humus system, including the upper part of the soil profile, litter included, and all its inhabitants (Zanella et al., 2018), changed when vegetation shifted from a type to another (Ponge et al., 1998). At the subalpine level, accumulated organic matter poorly transformed by soil organisms (mor humus system) was characteristic of the ericaceous heath (Frak \& Ponge, 2002) while organic matter rapidly incorporated by earthworms (mull humus system) and accumulated organic matter transformed in humus by fungi and animals (moder 
humus system) alternated among regeneration and growth phases of the spruce forest cycle, respectively (Bernier \& Ponge, 1994). The bilberry heath, normally located above the tree line along a mountain slope, was shown to creep within the subalpine forest, taking advantage of canopy openings operated by foresters to improve light conditions at the ground surface, and changing abruptly the humus system. This unwanted invasion results in a total arrest of the natural regeneration of spruce, mediated by allelopathic processes (Gallet, 1994). The downslope encroachment of the heath ecosystem is a community-level amplification of small-scale processes taking place at the ramet level, in particular the conjunction of the sympodial growth of Vaccinium myrtillus with the asymmetry created by plagiotropism on sloping terrains (Maubon et al., 1995). As a result, the managed forest at the upper subalpine level has been rapidly transformed in a patchwork of spruce canopies (spruce ecosystem) and bilberry patches (heath ecosystem) which can be explained by properties of three ecological engineers: bilberry, a mor-forming plant, spruce, a moder-forming tree which regenerates only on mull, and the common mull-forming earthworm Lumbricus terrestris. L. terrestris is absent under bilberry while present in regeneration and mature growth stages of spruce. This soil-dwelling litter-feeding earthworm is able to transform moder in mull when conditions become favourable, i.e. after the end of the period of intense growth of spruce (Ponge \& Bernier, 1995).

In terrestrial environments, the observation of abrupt changes in humus systems is often indicative of community boundaries associated with alternative stable states (Beisner et al., 2003) or stages of vegetation dynamics (Van der Maarel, 1988). Such shifts have been observed along transect lines crossing complex vegetation patchworks (Sarthou et al., 2010), under tree (Beniamino et al., 1991) or even shrub (Peltier et al., 2001) canopies, as well as along pollution gradients (Gillet \& Ponge, 2002). The existence of tight relationships between producers (plants) and decomposers (microbes, saprophagous animals), finely tuned in the course of humus development (Ponge, 2003, 2013a), has been exemplified in the 'home field advantage' hypothesis (Ayres et al., 2009). According to this hypothesis microbial assemblages present in a given place ('at home') are better prone to decay the litter produced by trees with which they were long time associated than that of any other 
introduced tree, and that whatever a priori differences in litter quality. This is an example of how an ecosystem engineer (here the tree) influences the composition of the community it has created.

Community boundaries created by functional domains of ecosystem engineers are not the apanage of terrestrial environments. Beyond the often-cited examples of corals and giant kelp as autogenic ecosystem engineers creating and harbouring a variegated community of vertebrates, invertebrates and microorganisms (Gates \& Ainsworth, 2011; Miller et al., 2018), let me cite the case of allogenic bioturbators in sediments (Bouma et al., 2009), which play the same role as earthworms, ants and termites in terrestrial environments (Lavelle et al., 2005). However, and that contrary to terrestrial environments, water bodies themselves, although harbouring trophic networks rivalling with the complexity of soil food webs, resist to the notion of ecosystem engineering because of the absence of physically stable functional domains, a particularity they share with atmospheric environments. Even it has been claimed that whales are marine ecosystem engineers (Roman et al., 2014) they look better like keystone species, a concept erected by Paine (1969) for species with a high trophic status, exerting cascading effects on the distribution and density of other species. Differences between ecosystem engineers and keystone species are discussed in a review chapter by De Visser et al. (2013).

Both Clements and Gleason did not take attention to the role of individuals in the community. However, each individual having engineering capabilities, whether autogenic or allogenic, is able to create a community, the boundaries of which can remain segregated, as in the individual establishment of trees within savannas or prairies (Archer et al., 2017), or may coalesce in the course of time, forming communities of a larger size (Rillig et al., 2016). Humans, as allogenic ecosystem engineers (Smith, 2007), have long-time created abrupt discontinuities within West and Central European landscapes. Heterogeneous landscapes historically managed by human activities attracted the attention of European plant sociologists towards the delineation of phytocoenoses, stemming in the rise of phytosociology (Braun-Blanquet, 1932), while American vegetation ecologists were attracted to presettlement landscapes where percolation processes were dominant, stemming in the continuum concept (McIntosh, 1967). 
In this section the role of ecosystem engineers acting at individual level in the delineation of communities has been emphasized. This community boundary is that of the functional domain of ecosystem engineers, whether allogenic (the environment directly or indirectly influenced by the ecosystem engineer) or autogenic (the ecosystem engineer itself). Several functional domains may collapse or be functionally interconnected, building the ecosystem.

\section{SPECIES INTERACTIONS ARE FASHIONED BY ECOSYSTEM ENGINEERS}

In a seminal paper Connell \& Slatyer (1977) proposed three models of mechanisms taking place in species interactions, called facilitation, tolerance and inhibition, in order of increasing contribution to community stability when faced to invaders. Here too, the role of dominant species was stressed as the main biological contribution to community change and stability. Expressing the three models in terms of community dynamics allowed better understanding how small-scale interactions among individuals explain community-wide processes of dynamics and stability. Here I suggest that dominant species, in the terms used by e.g. Connell \& Slatyer (1977) and Grime (1987), are ecosystem engineers, because they modify the physical environment of subordinate species (e.g. light). Interestingly, the facilitation model stimulated the search for positive interactions among members of communities even if the original concept just described processes by which a given species favours the establishment of another species, prone to succeed it. Facilitation, in the sense of positive interactions among species, became included in the ecological theory, which was previously based mainly on competition and predation, i.e. on negative interactions (Bruno et al., 2003). Cooperation among species occupying the same niche became accepted as an alternative to niche partitioning, the dominant tenet of theoretical ecology until a couple of decades ago, and that despite an early demonstration by Leigh (1983) that group selection overrides individual selection, or in ecological terms that cooperation is more advantageous than competition. Examples of cooperation have been found in terrestrial communities, e.g. common mycorrhizal networks (CMNs) helping to share resources (He et al., 2003) and exchange chemical signals (Barto et al., 2012) among plants of the same or various species. However, it has also been shown that in the presence of low-sociability plants CMNs contribute to mediate competition (Kytövhta et al., 2003). The social habit, when expressed by plants (Salisbury, 1931), animals (Krause 
\& Ruxton, 2002), or microbes (Sheela et al., 2018), seems thus a pre-requisite for the prevalence of cooperation over competition. I suggest that cooperation is favoured within functional domains of ecosystem engineers, stable conditions of which allow the development of cooperation within communities (Lavelle et al., 2016). Cooperation is also possible among ecosystem engineers when the environment is modified not by a single organism but by a chain of organisms, each of them processing a product, e.g. litter, already transformed upstream by another ecosystem engineer (Heard, 1994; Passarelli et al., 2014). Processing chains can explain successions observed in the course of decomposition (Paradise, 2000; Ponge, 2005b). Several engineers may also interact and display synergetic effects, like in core microbiota of plant-earthworm interactions (Jacquiod et al., 2020).

We may now question whether complex community-wide mutualisms (Thompson, 2006; Pohnert, 2010; Amsler et al., 2014) have evolved either in a directional manner towards the building of integrated super-organisms or in an opportunistic manner as constantly changing assembly processes. While it is a matter of fact that communities are shaped by the interplay between positive and negative species interactions (Xiao et al., 2009) it can be expected that positive interactions help communities to better resist environmental hazards (Bertness \& Callaway, 1994; Michalet et al., 2006), while negative interactions help them to better resist invasions (Case, 1990). In the absence of a community-level protection, offered by ecosystem engineers, invaders may take opportunity of mutualistic interactions (Rudgers et al., 2005) or on the contrary may disrupt them (Inderjit \& Van der Putten, 2010; Traveset \& Richardson, 2014), both ways favouring their successful establishment in the invaded community. Thus a combination of positive and negative interactions, expressed by a higher variety of interaction types, seems to be the most efficient selection pathway to ensure stability at community level (Mougi \& Kondoh, 2012), and that stability is ensured by ecosystem engineers (Jones et al., 1997). Most stable communities are not those exhibiting the more species but rather those with more non-random multiple-species interactions (Bairey et al., 2016), community-level processes being optimized by functional complementarity (Heemsbergen et al., 2004).

It is now of wide acceptance that diffuse co-evolution (Fox, 1988) and eco-evolutionary feedbacks (Post \& Palkovacs, 2009; Ponge, 2020) contributed to explain evolution in a species 
interaction context, at both micro- and macroevolutionary levels (terHorst et al., 2018). However, that natural selection might occur at community level is still largely speculative, even if well-known from a theoretical point of view (Johnson \& Boerlijst, 2002; Traulsen \& Nowak, 2006). The ITSNTS theory of Doolittle \& Inkpen (2018), in particular, claims that processes implemented in communities can be considered as units of selection based on the persistence of species interactions rather than on species reproduction. Briefly speaking, this theory, based on recent developments in microbiomics, enlarges the concept of adaptation to community activities ("functions"), which appear to be more stable than species assemblages carrying them out. In this context, the evolutionary role of ecosystem engineers and their functional domains might have to be reassessed in the frame of niche-construction (Day et al., 2003) and self-organization (Lavelle et al., 2016) theories.

In this section the role of ecosystem engineers as modulators of species interactions has been emphasized, with their functional domains as the seat of stable positive interactions favouring coevolution.

\section{ECOLOGICAL ENGINEERING EXISTS AT VARIOUS SCALES}

I suggest that communities exist, and have evolved, at various scales through ecosystem engineering. Like ecosystems (Tansley, 1935), communities can be considered as functional units embedded in a flexible manner. Let me take two examples. First, the rhizosphere, i.e. the root functional domain (Lavelle et al., 2005), has been considered as an ecosystem itself embedded in the soil ecosystem (Ponge, 2015). The rhizosphere harbours a 'microbial loop' which encompasses interconnected root tips, bacteria and protozoa (Coleman, 1994). The interplay of these three functional groups contributes to the recycling of nutrients in a form available to the plant, with a priming effect from root exudates and a change in the physical environment resulting from root growth (Clarholm, 1985). I suggest rising the root tip to the rank of ecosystem engineer and its associated microbial loop to the rank of community. It has been shown experimentally that interacting species in spatially-structured environments may evolve towards stable genetic assemblages (Hansen et al., 2007), supporting the idea that positive species interactions played a pivotal role in the diversification and organization of 
323 life (Thompson, 1999). Logically, three basic conditions are required, all three encountered in the

324 functional domains of ecological engineers, i.e. close spatial proximity of the species,

325 complementarity of their functions, and stability of the environment, increasing in turn in the process

326 of selection (Nowak, 2006). Vannier (1987) erected the concept of porosphere to explain the analogy

327 between soil and sea, and the role of the pore space in the evolution of soil organisms of marine origin.

328 In the frame of his concept I suggest that sea microbial loops, i.e. interactions between bacteria,

329 protozoa and an autotrophic producer, to which are now added viruses (Fenchel, 2008), colonized

330 primitive soils in which organisms continued to evolve in a terrestrial environment without losing their

331 ancestral functional links, and that roots, associated with other soil ecosystem engineers (e.g.

332 earthworms) created the conditions necessary for this evolution. Biological crusts, as extant

333 representatives of the most primitive soils (Kremer et al., 2018), and at the start of primary plant

334 successions (Yoshitake et al., 2010), harbour a variety of bacteria associated with filamentous

335 autotroph cyanobacteria (Liu et al., 2017), in which the observed abundance and functional variety of

336 protozoa (Bamforth, 2008) makes microbial loops highly probable as ancestors of the rhizosphere

337 microbial loop.

A further illustration of an embedded community is the internal microbiome of vertebrates

339 (Colston \& Jackson, 2016), the gut being the ecosystem (Aw \& Fukuda, 2015), and the animal the

340 ecosystem engineer. Microbial communities harboured by gut vertebrates come from a selection by

341 the intestinal epithelium of strains taken in the environment, with further amplification of favourable

342 strains (Schluter \& Foster, 2012). They ensure a myriad of functions having a strong impact on host

343 physiology and evolution through their prominent role in vertebrate adaptation (Sharpton, 2018).

344 Although the study of co-evolutionary processes between the microbiome (the community) and the

345 host (the ecosystem engineer) is still incipient (Sharpton, 2018), it can be suspected that these

346 processes have some bearing with the first steps of the evolution of the eukaryotic cell (the ecosystem

347 engineer), with the hypothesis that the first eukaryotic endomembranes had a secretory function which

348 selectively attracted archaebacteria (Jékely, 2003). 
According to the generalised community concept which I propound in this perspective paper, I

suggest that communities are fashioned by ecosystem engineering at a wide range of spatial and temporal scales, the finer the scale the higher the level of integration and common evolution of biotic components. In the eukaryiotic cell, the components originally inherited from the environment, e.g. cytoplasm, nucleus, plastids (Hartman \& Fedorov, 2002), cannot longer live separately. In the mycorrhizal symbiosis, the root and the fungus can be cultured separately, their association being nevertheless profitable to both partners, which exchange recognition signals (Harrison, 2005). In some cases, like when the balance between cost and benefit is perturbed, the symbiotic fungus may invade and parasitize or even destroy its host (Johnson et al., 1997), showing that the mycorrhizal association is conditioned by stability of the environment. In the vertebrate gut, as shown above, bacteria selected from the environment complement the enzymatic equipment of the host, which in turn offers a stable, mild environment to the bacterial flora. Here too, the microbiome may evolve in a manner unfavourable to the host, promoting a disease which necessitates a complete renewal of the harboured microflora (Lynch \& Pedersen, 2016). At a still larger scale communities harbour a variety of organisms belonging to groups as remote as plants, microbes and animals. These organisms interacted and evolved together or in the presence of functionally equivalent partners, now extinct but with their interactions still surviving. This has been exemplified in the concept of niche construction, considering that organisms modify their own selective environment (Odling-Smee et al., 1996, 2013). It is suggested that niche construction is mainly ensured by ecosystem engineers, the master piece of communities (Erwin, 2008), mainly those of the allogenic type, the biogenic structures they create survive long-time after their death (Curran, 1985).

In this section the variety of scales at which ecosystem engineering is present was emphasized. As a result of activities of ecosystem engineers of varying size, from viruses to trees (or coral reefs), communities and their physical environment (the ecosystem) are embedded, allowing us to disentangle their apparent complexity. 
Providing key interactions are maintained within the community (Hale et al., 2015), changes in species composition do not affect community level properties such as stability (Saint-Béat et al., 2015). Given that most interactions are under the control of ecosystem engineers (Jones et al., 1994), their presence, not necessarily as species but rather as functional groups, is a prerequisite for the sustainability or restoration of the community (Byers et al., 2006). When an ecosystem engineer, in particular of the autogenic type, is negatively affected by an environmental change, then the whole community is at risk, as can be observed in collapsing forests, coral reefs and sphagnum bogs (Jones et $a l .$, 1997). As an example, the climate-induced bleaching of coral reefs in the Indian Ocean drove the decline of members of the coral feeding community (Graham et al., 2009).

Conversely, because some invasive species are also efficient ecosystem engineers in both aquatic and terrestrial environments (Sousa et al., 2009; Maurel et al., 2010), dramatic changes are expected to occur following expansion of their geographic area, and these changes may occur whether ecosystem engineers are of the autogenic or allogenic type. Although not related to climate warming, the colonisation of North America by European lumbricid earthworms, progressing westwards from the first European settlements, has changed to a great extent the floristic composition of northern temperate forests (Hoffensperger et al., 2011). Under the activity of burrowing earthworms, typical allogenic engineers (Lavelle et al., 2016), the thick forest floor disappears, triggering a pronounced change in the humus system (Bohlen et al., 2004) with negative bottom-up effects on indigenous fauna (Migge-Kleian et al., 2006). In Europe, where lumbricid earthworms are in their natural area of distribution, northward earthworm invasions can also be predicted on the base of the observed relationship between temperature and humus form (Ponge et al., 2011). Changes in the humus system will take place at a rate dictated by the slow rate of dispersal of earthworms (Marinissen \& Van den Bosch, 1992), with dramatic changes expected to occur within a few decades in boreal forests on the model of what has already happened in North-American temperate forests. Shifts in humus systems under the postulated increase in earthworm activity, namely from moder or even mor to mull (Ponge et al., 2011), will also favour the establishment of tree seedlings (Ponge et al., 1998), still increasing the climate-driven latitudinal and altitudinal encroachment of forest ecosystems which has been observed 
in boreal and mountain areas (Kullman and Öberg, 2009). As predicted by the theory of alternate stable states (Holling, 1973), verified in both aquatic (Van de Koppel et al., 2001) and terrestrial environments (Augustine et al., 1998), it is highly probable that a new equilibrium will be achieved by local adaptation (Kawecki \& Ebert, 2004) and modifications in the sequence of community assembly during recolonization (Price \& Morin, 2004), but the process can be slow if some functions are lost because of a population bottleneck (Obadia et al., 2017). I suggest that ecosystem engineers play potentially a key role of as "centres of gravity" for other community members in the transition period between alternate stable states, being drivers of positive feedbacks (Lavelle et al., 2016). With their facilitating properties ecosystem engineers could become key agents of restoration measures (Schotanus et al., 2020).

Among ecosystem engineers, and according to our extension of the concept of community from cells to landscapes, viruses should not be forgotten (Witzany, 2012). Present-day increases in long-distance travels (Thomson \& Nájera, 2001), air pollution (Ciencewicki \& Jaspers, 2007) and rapid and/or erratic environmental changes (Paz, 2015) favour these opportunist allogenic engineers of the cell machinery and beyond (Suttle, 2007), now known to have played a prominent role in the evolution of life (Jalasvuori \& Bamford, 2008). It can be predicted that they will also took a more and more prominent place in the present-day sixth extinction, with a feed-back from biodiversity losses to virulence for human populations (Ostfeld, 2009).

In this section positive as well as negative roles played by ecosystem engineers were highlighted in the frame of global changes. It was shown in this section that ecosystem engineers can be actors as well as victims of changes observed at global scale, with cascading effects on members of the communities they contribute to fashion.

\section{CONCLUSIONS}

In this study I argued that (i) communities boundaries are determined by the physical limits of ecosystem engineers' functional domains, (ii) species interactions within communities are controlled by cooperation among ecosystem engineers, (iii) communities exist and have evolved at various 
scales, determined by embedded functional domains of ecosystem engineers, and (iv) the stability of communities is ensured by interactions among ecosystem engineers, which collapse when environmental changes are too rapid.

\section{ACKNOWLEDGEMENTS}

I warmly acknowledge Manuel Blouin for fruitful discussions, in particular when he brought to the attention of the author the distinction between autogenic and allogenic engineers. I also acknowledge three anonymous reviewers who commented on a previous draft of this paper and contributed to its improvement by refining the concepts and making the story more straightforward.

\section{REFERENCES}

Abades, S.R., Gaxiola, A. \& Marquet, P.A. (2014). Fire, percolation thresholds and the savanna forest transition: a neutral model approach. J. Ecol., 102, 1386-1393.

Abrams, P.A. (1986). Adaptive responses of predators to prey and prey to predators: the failure of the arms-race analogy? Evolution, 40, 1229-1247.

Amsler, C.D., McClintock, J.B., Baker, B.J. \& Graham, M. (2014). Chemical mediation of mutualistic interactions between macroalgae and mesograzers structure unique coastal communities along the western Antarctic Peninsula. J. Phycol., 50, 1-10.

Archer, S.R., Andersen, E.M., Predick, K.I., Schwinning, S., Steidl, R.J. \& Woods, S.R. (2017). Woody plant encroachment: causes and consequences. In: Rangeland systems: processes, management and challenges (ed. Briske, D.D.). Springer, Cham, Switzerland, pp. 25-83.

Augustine, D.J., Frelich, L.E. \& Jordan, P.A. (1998). Evidence for two alternate stable states in an ungulate grazing system. Ecol. Applic., 8, 1260-1269.

Aussenac, G. (2000). Interactions between forest stands and microclimate: ecophysiological aspects and consequences for silviculture. Ann. For. Sci., 57, 287-301. 
Aw, W.P. \& Fukuda, S. (2015). Toward the comprehensive understanding of the gut ecosystem via metabolomics-based integrated omics approach. Semin. Immunopathol., 37, 5-16.

Ayres, E., Steltzer, H., Simmons, B.L., Simpson, R.T., Steinweg, J.M., Wallenstein et al. (2009). Home-field advantage accelerates leaf litter decomposition in forests. Soil Biol. Biochem., 41, 606-610.

Azam, F., Fenchel, T., Field, J.G., Gray, J.S., Meyer-Reil, L.A. \& Thingstad, F. (1983). The ecological role of water-column microbes in the sea. Marine Ecol Progr Series, 10, 257-263.

Bairey, E., Kelsic, E.D. \& Kishony, R. (2016). High-order species interactions shape ecosystem diversity. Nat. Commun., 7, 12285.

Bamforth, S.S. (2008). Protozoa of biological soil crusts of a cool desert in Utah. J. Arid Environ., 72, $722-729$.

Barto, E.K., Weidenhamer, J.D., Cipollini, D. \& Rillig, M.C. (2012). Fungal superhighways: do common mycorrhizal networks enhance below ground communication? Trends Plant Sci., 17, $633-637$.

Beisner, B.E., Haydon, D.T. \& Cuddington, K. (2003). Alternative stable states in ecology. Front. Ecol. Environ., 1, 376-382.

Bell, S.S., McCoy, E.D. \& Mushinsky, H.R. (1990). Habitat structure: the physical arrangement of objects in space. Chapman and Hall, London, United Kingdom.

Beniamino, F., Ponge, J.F. \& Arpin, P. (1991). Soil acidification under the crown of oak trees. I. Spatial distribution. Forest Ecol. Manage., 40, 221-232.

Bernier, N. \& Ponge, J.F. (1994). Humus form dynamics during the sylvogenetic cycle in a mountain spruce forest. Soil Biol. Biochem., 26, 183-220.

Bertness, M.D. \& Callaway, R., 1994. Positive interactions in communities. Trends Ecol. Evol., 9, 191-193. 
Bohlen, P.J., Scheu, S., Hale, C.M., McLean, M.A., Migge, S., Groffman, P.M. et al. (2004). Nonnative invasive earthworms as agents of change in northern temperate forests. Front. Ecol. Environ., 2, 427-435.

Bouma, T.J., Olenin, S., Reise, K. \& Ysebaert, T. (2009). Ecosystem engineering and biodiversity in coastal sediments: posing hypotheses. Helgol. Mar. Res., 63, 95-106.

Braun-Blanquet, J. (1932). Plant sociology: the study of plant communities. McGraw-Hill, New York, New York.

Bruno, J.F., Stachowicz, J.J. \& Bertness, M.D. (2003). Inclusion of facilitation into ecological theory. Trends Ecol. Evol., 18, 119-125.

Byers, J.E., Cuddington, K., Jones, C.G., Talley, T.S., Hastings, A., Lambrinos, J.G. et al. (2006). Using ecosystem engineers to restore ecological systems. Trends Ecol. Evol., 21, 493-500.

Callaway, R.M. (2002). The detection of neighbors by plants. Trends Ecol. Evol., 17, 104-105.

Cameron, D.D. (2010). Arbuscular mycorrhizal fungi as (agro)ecosystem engineers. Plant Soil, 333, $1-5$.

Case, T.J. (1990). Invasion resistance arises in strongly interacting species-rich model competition communities. Proc. Natl Acad. Sci. USA, 87, 9610-9614.

Castorani, M.C.N., Hovel, K.A., Williams, S.L. \& Baskett, M.L. (2014). Disturbance facilitates the coexistence of antagonistic ecosystem engineers in California estuaries. Ecology, 95, 22772288.

Ciencewicki, J. \& Jaspers, I. (2007). Air pollution and respiratory viral infection. Inhal Toxicol., 19, $1135-1146$.

Clarholm, M. (1985). Interactions of bacteria, protozoa and plants leading to mineralization of soil nitrogen. Soil Biol. Biochem., 17, 181-187. 
Clements, F.E. (1916). Plant succession: an analysis of the development of vegetation. Carnegie Institution of Washington, Washington, District of Columbia.

Clements, F.E. (1936). Nature and structure of the climax. J. Ecol., 24, 252-284.

Coleman, D.C. (1994). The microbial loop concept as used in terrestrial soil ecology studies. Microb. Ecol., 28, 245-250.

Coleman, F.C. \& Williams, S.L. (2002). Overexploiting marine ecosystem engineers: potential consequences for biodiversity. Trends Ecol. Evol., 17, 40-44.

Colston, T.J. \& Jackson, C.R. (2016). Microbiome evolution along divergent branches of the vertebrate tree of life: what is known and unknown. Mol. Ecol., 25, 3776-3800.

Commito, J.A., Celano, E.A., Celico, H.J., Como, S. \& Johnson, C.P. (2005). Mussels matter: postlarval dispersal dynamics altered by a spatially complex ecosystem engineer. $J$. Exp. Marine Biol. Ecol., 316, 133-147.

Connell, J.H. (1980). Diversity and the coevolution of competitors, or the ghost of competition past. Oikos, 35, 131-138.

Connell, J.H. \& Slatyer, R.O. (1977). Mechanisms of succession in natural communities and their role in community stability and organization. Am. Nat., 111, 1119-1144.

Curran, H.A. (1985). Biogenic structures: their use in interpreting depositional environments. Society of Economic Paleontologists and Mineralogists, Tulsa, Oklahoma.

Curtis, J.T. (1955). A prairie continuum in Wisconsin. Ecology, 36, 558-566.

Danz, N.P., Frelich, L.E., Reich, P.B. \& Niemi, G.J. (2013). Do vegetation boundaries display smooth or abrupt spatial transitions along environmental gradients? Evidence from the prairie-forest biome boundary of historic Minnesota, USA. J. Veg. Sci., 24, 1129-1140. 
Darwin, C. (1859). On the origin of species by means of natural selection, or the preservation of favoured races in the struggle for life. John Murray, London, England.

Day, R.L., Laland, K.N. \& Odling-Smet, J. (2003). Rethinking adaptation: the niche-construction perpective. Persp. Biol. Medic., 46, 80-95.

De Visser, S., Thébault, E. \& De Ruiter, P.C. (2013). Ecosystem engineers, keystone species. In: Ecological systems: selected entries from the Encyclopedia of Sustainability Science and Technology (ed. Leemans, R.). Springer, New York, New York, pp. 59-68.

Domb, C. \& Lebowitz, J.L. (2000). Phase transitions and critical phenomena, volume 19. Academic Press, London, United Kingdom.

Doolittle, W.F. \& Inkpen, S.A. (2018). Processes and patterns of interaction as units of selection: an introduction to ITSNTS thinking. Proc. Natl Acad. Sci. USA, 115, 4006-4014.

Erwin, D.H. (2008). Macroevolution of ecosystem engineering, niche construction and diversity. Trends Ecol. Evol., 23, 304-310.

Fenchel, T. (2008). The microbial loop: 25 years later. J. Exp. Marine Biol. Ecol., 366, 99-103.

Fox, L.R. (1988). Diffuse coevolution within complex communities. Ecology, 69, 906-907.

Frak, E. \& Ponge, J.F. (2002). The influence of altitude on the distribution of subterranean organs and humus components in Vaccinium myrtillus carpets. J. Veg. Sci., 13,17-26.

Gallet, C. (1994). Allelopathic potential in bilberry-spruce forests: influence of phenolic compounds on spruce seedlings. J. Chem. Ecol., 20, 1009-1024.

Gates, R.D. \& Ainsworth, T.D. (2011). The nature and taxonomic composition of coral symbiomes as drivers of performance limits in scleractinian corals. J. Exp. Mar. Biol. Ecol., 408, 94-101.

Gillet, S. \& Ponge, J.F. (2002). Humus forms and metal pollution in soil. Eur. J. Soil Sci., 53, 529539. 
Gleason, H.A. (1926). The individualistic concept of the plant association. Bull. Torrey Bot. Club, 53, $7-26$.

Gleason, H.A. (1939). The individualistic concept of the plant association. Am. Midl. Nat., 21, 92-110.

Graham, N.A.J., Wilson, S.K., Pratchett, M.S., Polunin, N.V.C., Spalding, M.D. (2009). Coral mortality versus structural collapse as drivers of corallivorous butterflyfish decline. Biodivers. Conserv., 18, 3325-3336.

Grime, J.P. (1987). Dominant and subordinate components of plant communities: implications for succession, stability and diversity. In: Colonization, succession and stability (eds. Gray, A.J., Crawley, M.J. \& Edwards, P.J.). Blackwell Scientific Publications, Oxford, United Kingdom, pp. 413-428.

Hale, R., Mavrogordato, M.N., Tolhurst, T.J. \& Solan, M. (2015). Characterizations of how species mediate ecosystem properties require more comprehensive functional effect descriptors. Sci. Rep., 4, 6463.

Hansen, S.K., Rainey, P.B., Haagensen, J.A.J. \& Molin, S. (2007). Evolution of species interactions in a biofilm community. Nature, 445, 533-536.

Harrison, M.J. (2005). Signaling in the arbuscular mycorrhizal symbiosis. Ann. Rev. Microbiol., 59, $19-42$.

Hartman, H. \& Fedorov, A. (2002). The origin of the eukaryotic cell: a genomic investigation. Proc. Natl Acad. Sci. USA, 99, 1420-1425.

He, X.H., Critchley, C. \& Bledsoe, C. (2003). Nitrogen transfer within and between plants through common mycorrhizal networks (CMNs). Crit. Rev. Plant Sci., 22, 531-567.

Heard, S.B. (1994). Processing chain ecology: resource condition and interspecific interactions. $J$. Anim. Ecol., 63, 451-464. 
567

568

569

570

571

572

573

574

575

576

577

578

579

580

581

582

583

584

585

586

587

588

589

Heemsbergen, D.A., Berg, M.P., Loreau, M., Van Hal, J.R., Faber, J.H. \& Verhoef, H.A. (2004). Biodiversity effects on soil processes explained by interspecific functional dissimilarity. Science, 306, 1019-1020.

Hoffensperger, K.N., Leighton, G.M. \& Fahey, T.J. (2011). Influence of invasive earthworms on above and belowground vegetation in a northern hardwood forest. Am. Midl. Nat., 166, 53-62.

Holling, C.S. (1973). Resilience and stability of ecological systems. Ann. Rev. Ecol. Syst., 4, 1-23.

Hubbell, S.P. (2001). The unified neutral theory of biodiversity and biogeography. Princeton University Press, Princeton, New Jersey.

Huston, J.H. (1994). Biological diversity: the coexistence of species on changing landscapes. Cambridge University Press, Cambridge, United Kingdom.

Inderjit \& Van der Putten, W.H. (2010). Impacts of soil microbial communities on exotic plant invasions. Trends Ecol. Evol., 25, 512-519.

Iwaki, H. \& Totsuka, T. (1959). Ecological and physiological studies on the vegetation of Mt. Shimagare. II. On the crescent-shaped "dead trees strips" in the Yatsugatake and the Chichibu mountains. Bot. Mag. Tokyo, 72, 225-260.

Jacquiod, S., Puga-Freitas, R., Spor, A., Mounier, A., Monard, C., Mougel, C. et al. (2020). A core microbiota of the plant-earthworm interaction conserved across soils. Soil Biol. Biochem., 144, 107754.

Jalasvuori, M. \& Bamford, J.K.H. (2008). Structural co-evolution of viruses and cells in the primordial world. Orig. Life Evol. Biosph., 38, 165-181.

Jékely, G. (2003). Small GTPases and the evolution of the eukaryotic cell. BioEssays, 25, 1129-1138.

Johnson, C.R. \& Boerlijst, M.C. (2002). Selection at the level of the community: the importance of spatial structure. Trends Ecol. Evol., 17, 83-90. 
Johnson, N.C., Graham, J.H. \& Smith, F.A. (1997). Functioning of mycorrhizal associations along the mutualism-parasitism continuum. New Phytol., 135, 575-585.

Jones, C.G., Lawton, J.H. \& Shachak, M. (1994). Organisms as ecosystem engineers. Oikos, 69, 373386.

Jones, C.G., Lawton, J.H. \& Shachak, M. (1997). Positive and negative effects of organisms as physical ecosystem engineers. Ecology, 78, 1946-1957.

Jouquet, P., Dauber, J., Lagerlöf, J., Lavelle, P. \& Lepage, M. (2006). Soil invertebrates as ecosystem engineers: intended and accidental effects on soil and feedback loops. Appl. Soil Ecol., 32, $153-164$.

Jouquet, P., Mathieu, J., Barot, S. \& Choosai, C. (2007). Soil engineers as ecosystem heterogeneity drivers. In: Ecology Research Progress (ed. Muñoz, S.I.). Nova Science Publishers, New York, New York, pp. 187-198.

Kawecki, T.J. \& Ebert, D. (2004). Conceptual issues in local adaptation. Ecol. Lett., 7, 1225-1241.

Krause, J. \& Ruxton, G.D. (2002). Living in groups. Oxford University Press, Oxford, United Kingdom.

Kremer, B., Kaźmierczak, J. \& Środoń, J. (2018). Cyanobacterial-algal crusts from Late Ediacaran paleosols of the East European Craton. Precambr. Res., 305: 236-246.

Kullman, L. \& Öberg, L. (2009). Post-Little Ice Age tree line rise and climate warming in the Swedish Scandes: a landscape ecological perspective. J. Ecol., 97, 415-429.

Kytövhta, M.M., Vestberg, M. \& Tuomi, J. (2003). A test of mutual aid in common mycorrhizal networks: established vegetation negates benefit in seedlings. Ecology, 84, 898-906.

Lavelle, P. (2002). Functional domains in soils. Ecol. Res., 17, 441-450. 
Lavelle, P., Rouland, C., Diouf, M., Binet, F. \& Kersanté, A. (2005). Regulation of microbial activities in functional domains of roots and invertebrates. In: Microorganisms in soils: roles in genesis and functions (eds. Buscot, F. \& Varma, A.). Springer, Berlin, Germany, pp. 291-305.

Lavelle, P., Spain, A., Blouin, M., Brown, G., Decaëns, T., Grimaldi, M. et al. (2016). Ecosystem engineers in a self-organized soil: a review of concepts and future research questions. Soil Sci., $181,91-109$.

Leibold, M.A., Holyoak, M., Mouquet, N., Amarasekare, P., Chase, J.M., Hoopes, M.F. et al. (2004). The metacommunity concept: a framework for multi-scale community ecology. Ecol. Lett., 7, $601-613$.

Leigh, E.G. Jr. (1983). When does the good of the group override the advantage of the individual? Proc. Natl Acad. Sci. USA, 80, 2985-2989.

Linné, C. von (1762). The oeconomy of nature. Dodsley, London, United Kingdom.

Liu, L.C., Liu, Y.B., Zhang, P., Song, G., Hui, R., Wang, Z.G. et al. (2017). Development of bacterial communities in biological soil crusts along a revegetation chronosequence in the Tengger Desert, northwest China. Biogeosci., 14, 3801-3814.

Loehle, C., Li, B.L. \& Sundell, R.C. (1996). Forest spread and phase transitions at forest-prairie ecotones in Kansas, U.S.A. Landscape Ecol., 11, 225-235.

Ludwig, J.A., Tongway, D.J. \& Marsden, S.G. (1999). Stripes, strands or stipples: modelling the influence of three landscape banding patterns on resource capture and productivity in semiarid woodlands, Australia. Catena, 37, 257-273.

Lynch, S.V. \& Pedersen, O. (2016). The human intestinal microbiome in health and disease. New England J. Med., 375, 2369-2379.

MacArthur, R.H. (1970). Species packing and competitive equilibria for many species. Theor. Pop. Biol., 1, 1-11. 
Marinissen, J.C.Y. \& Van den Bosch, F. (1992). Colonization of new habitats by earthworms. Oecologia, 91, 371-376.

Maubon, M., Ponge, J.F. \& André, J. (1995). Dynamics of Vaccinium myrtillus patches in mountain spruce forest. J. Veg. Sci., 6, 343-348.

Maurel, N., Salmon, S., Ponge, J.F., Machon, N., Moret, J. \& Muratet, A. (2010). Does the invasive species Reynoutria japonica have an impact on soil and flora in urban wastelands? Biol. Invas., 12, 1709-1719.

McIntosh, R.P. (1967). The continuum concept of vegetation. Bot. Rev., 33, 130-187.

Michalet, R., Brooker, R.W., Cavieres, L.A., Kikvidze, Z., Lortie, C.J., Pugnaire, F.I. et al. (2006). Do biotic interactions shape both sides of the humped-back model of species richness in plant communities? Ecol. Lett., 9, 767-773.

Migge-Kleian, S., McLean, M.A., Maerz, J.C. \& Heneghan, L. (2006). The influence of invasive earthworms on indigenous fauna in ecosystems previously uninhabited by earthworms. Biol. Invas., 8, 1275-1285.

Miller, R.J., Lafferty, K.D., Lamy, T., Kui, L., Rassweiler, A. \& Reed, D.C. (2018). Giant kelp, Macrocystis pyrifera, increases fainal diversity through physical engineering. Proc. R. Soc. B, $285,20172571$.

Milne, B.T., Johnson, A.R., Keitt, T.H., Hatfield, C.A., David, J. \& Hraber, P.T. (1996). Detection of critical densities associated with piñon-juniper woodland ecotones. Ecology, 77, 805-821.

Mougi, A. \& Kondoh, M. (2012). Diversity of interaction types and ecological community stability. Science, 337, 349-351.

Nowak, M.A. (2006). Five rules for the evolution of cooperation. Science, 314, 560-563.

Obadia, B., Güvener, Z.T., Zhang, V., Ceja-Navarro, J.A., Brodie, E.L., Ja, W.W. et al. (2017). Probabilistic invasion underlies natural gut microbiome stability. Curr. Biol., 27, 1999-2006. 
660

661

662

663

664

665

666

667

668

669

670

671

672

673

674

675

676

677

678

679

680

681

Odling-Smee, J., Erwin, D.H., Palkovacs, E.P., Feldman, M.W. \& Laland, K.N. (2013). Niche construction theory: a practical guide for ecologists. Q. Rev. Biol., 88, 3-28.

Odling-Smee, J., Laland, K.N. \& Feldman, L.W. (1996). Niche construction. Am. Nat., 147, 641-648.

Oldeman, R.A.A. (1990). Forests: elements of silvology. Springer, Berlin, Germany.

Ortiz, M., Levins, R., Campos, L., Berrios, F., Campos, F., Jordán, F. et al. (2013). Identifying keystone trophic groups in benthic ecosystems: implications for fisheries management. Ecol. Indic., 25, 133-140.

Ostfeld, R.S. (2009). Biodiversity loss and the rise of zoonotic pathogens. Clin. Microbiol. Infect., 15, S40-S43.

Paine, R.T. (1969). A note on trophic complexity and community stability. Am. Nat., 103, 91-93.

Paradise, C.J., 2000. Effects of $\mathrm{pH}$ and resources on a processing chain interaction in simulated treeholes. J. Anim. Ecol., 69, 651-658.

Passarelli, C., Olivier, F., Paterson, D.M., Meziane, T. \& Hubas, C. (2014). Organisms as cooperative ecosystem engineers in intertidal flats. J. Sea Res., 92, 92-101.

Paz, S. (2015). Climate change impacts on West Nile virus transmission in a global context. Phil. Trans. R. Soc. London B, 370, 20130561.

Peltier, A., Ponge, J.F., Jordana, R. \& Ariño, A. (2001). Humus forms in Mediterranean scrublands with Aleppo pine. Soil Sci. Soc. Am. J., 65, 884-896.

Pimm, S.L. (1980). Properties of food webs. Ecology, 61, 219-225.

Pohnert, G. (2010). Chemical noise in the silent ocean. J. Plankt. Res., 32, 141-144.

Ponge, J.F. (2003). Humus forms in terrestrial ecosystems: a framework to biodiversity. Soil Biol. Biochem., 35, 935-945. 
682

683

684

685

686

687

688

689

690

691

692

693

694

695

696

697

698

699

700

701

702

703

Ponge, J.F. (2005a). Emergent properties from organisms to ecosystems: towards a realistic approach. Biol. Rev., 80, 403-411.

Ponge, J.F. (2005b). Fungal communities: relation to resource succession. In: The fungal community: its organization and role in the ecosystem (eds. Dighton, J., White, J.F. \& Oudemans, J.). Taylor and Francis, Boca Raton, Florida, pp. 169-180.

Ponge, J.F. (2013a). Plant-soil feedbacks mediated by humus forms: a review. Soil Biol. Biochem., 57, $1048-1060$.

Ponge, J.F. (2015). The soil as an ecosystem. Biol. Fertil. Soils, 51, 645-648.

Ponge, J.F. (2020). Move or change, an eco-evolutionary dilemma: the case of Collembola. Pedobiologia, 79, 150625.

Ponge, J.F., André, J., Zackrisson, O., Bernier, N., Nilsson, M.C. \& Gallet, C. (1998). The forest regeneration puzzle. BioSci., 48, 523-530.

Ponge, J.F. \& Bernier, N. (1995). Changes in humus forms and forest dynamics in the French northern Alps. In: Functioning and dynamics of natural and perturbed ecosystems (eds. Bellan, D., Bonin, G. \& Emig, C.). Lavoisier, Paris, pp. 174-182.

Ponge, J.F., Jabiol, B. \& Gégout, J.C. (2011). Geology and climate conditions affect more humus forms than forest canopies at large scale in temperate forests. Geoderma, 162, 157-195.

Post, D.M. \& Palkovacs, E.P. (2009). Eco-evolutionary feedbacks in community and ecosystem ecology: interactions between the ecological theatre and the evolutionary play. Phil. Trans. $R$. Soc. London B, 364, 1629-1640.

Price, J.E. \& Morin, P.J. (2004). Colonization history determines alternate community states in a food web of intraguild predators. Ecology, 85, 1017-1028. 
Rajakaruna, N., Bradfield, G.E., Bohm, B.A. \& Whitton, J. (2003). Adaptive differentiation in response to water stress by edaphic races of Lasthenia californica (Asteraceae). Int. J. Plant Sci., 164, 371-376.

Ratzke, C., Barrere, J. \& Gore, J. (2020). Strength of species interactions determines biodiversity and stability in microbial communities. Nature Ecol. Evol., 4, 376-383.

Rillig, M.C., Lehmann, A., Aguilar-Trigueros, C.A., Antonovics, J., Caruso, T., Hempel, S. et al. (2016). Soil microbes and community coalescence. Pedobiologia, 59, 37-40.

Roman, J., Estes, J.A., Morissette, L., Smith, C., Costa, D. et al. (2014). Whales as marine ecosystem engineers. Front. Ecol. Environ., 12, 377-385.

Rudgers, J.A., Mattingly, W.B. \& Koslow, J.M. (2005). Mutualistic fungus promotes plant invasion into diverse communities. Oecologia, 144, 463-471.

Saint-Béat, B., Baird, D., Asmus, H., Asmus, R., Bacher, C., Pacella, S.R. et al. (2015). Trophic networks: how do theories link ecosystem structure and functioning to stability properties? A review. Ecol. Indic., 52, 458-471.

Salisbury, E.J. (1931). The standardisation of descriptions of plant communities. J. Ecol., 19, 177189.

Sarthou, C., Larpin, D., Fonty, É., Pavoine, S. \& Ponge, J.F. (2010). Stability of plant communities along a tropical inselberg ecotone in French Guiana (South America). Flora, 205, 682-694.

Schluter, J. \& Foster, K.R. (2012). The evolution of mutualism in gut microbiota via host epithelial selection. PLoS Biol., 10, e1001424.

Schotanus, J., Walles, B., Capelle, J.J., Van Belzen, J., Van de Koppel, J. \& Bouma, T.J. (2020). Promoting self-facilitating feedback processes in coastal ecosystem engineers to increase restoration processes: testing engineering measures. J. Appl. Ecol., 57, 1958-1968.

Sharpton, T.J. (2018). Role of the gut microbiome in vertebrate evolution. mSystems, 3, e00174-17. 
Sheela, G.M., Prathyusha, A.M.V.N., Neelapu, N.R.R. \& Bramhachari, P.V. (2018). Intra and interspecies communication in microbes: living with complex and sociable neighbors. In: Implication of quorum sensing system in biofilm formation and virulence (ed. Bramhachari, P.V.). Springer, Singapore, Singapore, pp. 7-16.

Sileshi, G.W., Arshad, M.A., Konaté, S. \& Nkunika, P.O.Y. (2010). Termite-induced heterogeneity in African savanna vegetation: mechanisms and patterns. J. Veg. Sci., 21, 923-937.

Smith, B.D. (2007). The ultimate ecosystem engineers. Science, 315, 1797-1798.

Sousa, R., Gutiérrez, J.L. \& Aldridge, D.C. (2009). Non-indigenous invasive bivalves as ecosystem engineers. Biol. Invas., 11, 2367-2385.

Sprugel, D.G. (1976). Dynamic structure of wave-regenerated Abies balsamea forests in the northeastern United States. J. Ecol., 64, 889-911.

Suttle, C.A. (2007). Marine viruses: major players in the global ecosystem. Nature Rev., 5, 801-812.

Takeda, H. (1995). Templates for the organization of collembolan communities. In: Structure and function of soil communities (eds. Edwards, C.A., Abe, T. \& Striganova, B.R.). Kyoto University Press, Kyoto, Japan, pp. 5-20.

Tansley, A.G. (1935). The use and abuse of vegetational concepts and terms. Ecology, 16, 284-307.

terHorst, C.P., Zee, P.C., Heath, K.D., Miller, T.E., Pastore, A.I., Patel, S. et al. (2018). Evolution in a community context: trait responses to multiple species interactions. Am. Nat., 191, 368-380.

Thompson, J.N. (1999). The evolution of species interactions. Science, 284, 2116-2118.

Thompson, J.N. (2006). Mutualistic webs of species. Science, 312, 372-373.

Thomson, M.M. \& Nájera, R. (2001). Travel and the introduction of human immunodeficiency virus type 1 non-B subtype genetic forms into western countries. Travel Medic., 32, 1732-1737. 
Tilman, D. (1982). Resource competition and community structure. Princeton University Press, New Jersey.

Tilman, D. (2004). Niche tradeoffs, neutrality, and community structure: a stochastic theory of resource competition, invasion, and community assembly. Proc. Natl Acad. Sci. USA, 101, $10854-10861$.

Traulsen, A. \& Nowak, M.A. (2006). Evolution of cooperation by multilevel selection. Proc. Natl Acad. Sci. USA, 103, 10952-10955.

Traveset, A. \& Richardson, D.M. (2014). Mutualistic interactions and biological invasions. Ann. Rev. Ecol. Evol. Syst., 45, 89-113.

Umbanhowar, C.E. Jr (1992). Reanalysis of the Wisconsin prairie continuum. Am. Midl. Nat., 127, $268-275$.

Van de Koppel, J., Herman, P.M.J., Thoolen, P. \& Heip, C.H.R. (2001). Do alternate stable states occur in natural ecosystems? Evidence from a tidal flat. Ecology, 82, 3449-3461.

Van der Maarel, E. (1988). Vegetation dynamics: patterns in time and space. Vegetatio, 77, 7-19.

Vannier, G. (1987). The porosphere as an ecological medium emphasized in Professor Ghilarov's work on soil animal adaptations. Biol. Fertil. Soils, 3, 39-44.

Watt, A.S. (1947). Pattern and process in the plant community. J. Ecol., 35, 1-22.

Watt, A.S. (1964). The community and the individual. J. Anim. Ecol., 33, 203-211.

Wilson, W.G., Nisbet, R.M., Ross, A.H., Robles, C. \& Desharnais, R.A. (1996). Abrupt population changes along smooth environmental gradients. Bull. Math. Biol., 58, 907-922.

Witzany, G. (2012). From molecular entities to competing agents: viral infection-derived consortia act as natural genetic engineers. In: Viruses: essential agents of life (ed. Witzany, G). Springer, Dordrecht, pp. 407-419. 
Wright, J.P., Gurney, W.S.C. \& Jones, C.G. (2004). Patch dynamics in a landscape modified by ecosystem engineers. Oikos, 105, 336-348.

Wright, J.P. \& Jones, C.G. (2006). The concept of organisms as ecosystem engineers ten years on: progress, limitations, and challenges. BioSci., 56, 203-209.

Xiao, S., Michalet, R., Wang, G. \& Chen, S.Y. (2009). The interplay between species' positive and negative interactions shapes the community biomass-species richness relationship. Oikos, 118, $1343-1348$.

Yamamura, N. (1976). A mathematical approach to spatial distribution and temporal succession in plant communities. Bull. Math. Biol., 38, 517-526.

Yoshitake, S., Uchida, M., Koizumi, H., Kanda, H. \& Nakatsubon, T. (2010). Production of biological soil crusts in the early stage of primary succession on a High Arctic glacier foreland. New Phytol., 186, 451-460.

Zanella, A., Ponge, J.F., Jabiol, B., Sartori, G., Kolb, E., Le Bayon, R.C. et al. (2018). Terrestrial humus systems and forms: keys of classification of humus systems and forms. Appl. Soil Ecol., 122, 75-86. 